\title{
Insulin-like growth factor-1 and zinc status of goitrous primary-school children in Arak, Islamic Republic of Iran
}

M.R. Rezvanfar, ${ }^{1}$ H. Farahany, ${ }^{2}$ M. Rafiee and B. Eshratee $^{3}$

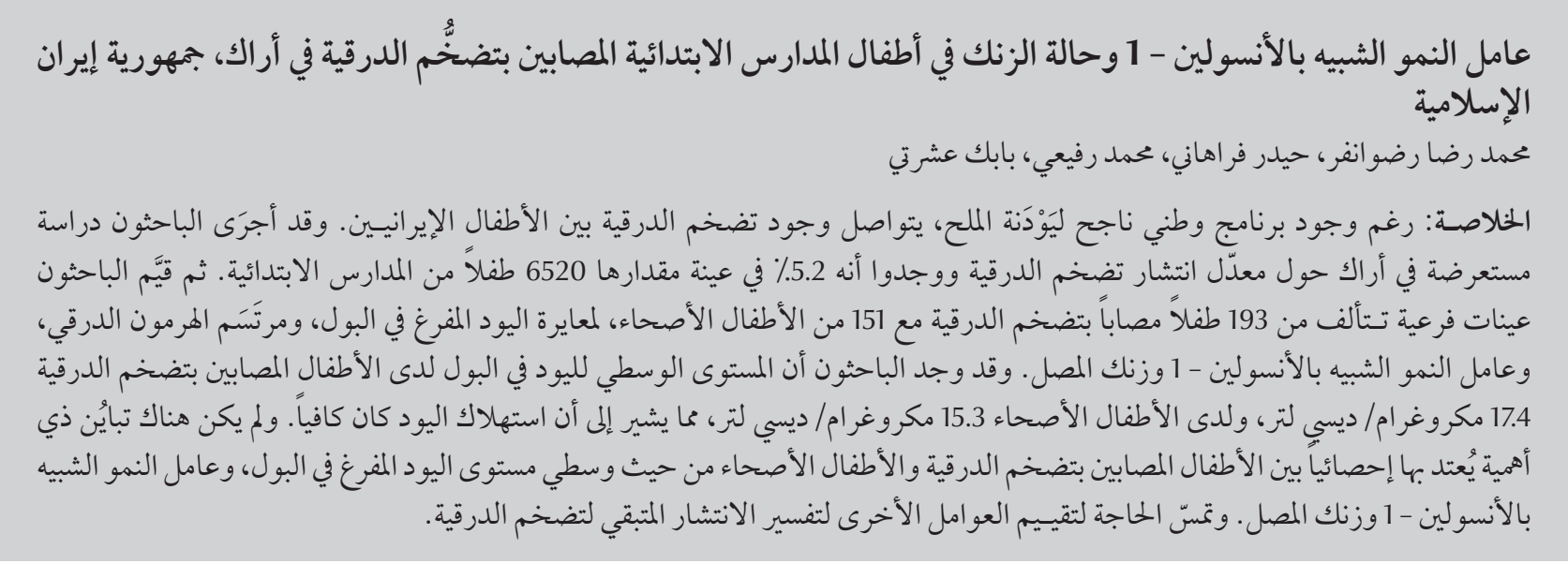

ABSTRACT Despite a successful national salt iodinization programme, endemic goitre still persists in Iranian children. In a cross-sectional study in Arak the prevalence of goitre was 5.2\% in a sample of 6520 primaryschool children. Subsamples of 193 children with goitre and 151 healthy children were assessed for urinary iodine excretion, thyroid hormone profile, insulin-like growth factor-1 (IGF-1) and serum zinc. The mean urinary iodine levels of goitrous children and healthy children were $17.4 \mu \mathrm{g} / \mathrm{dL}$ and $15.3 \mu \mathrm{g} / \mathrm{dL}$ respectively, suggesting that iodine consumption was adequate. No significant differences were found between goitrous and healthy schoolchildren in mean levels of urinary iodine, serum IGF-1 or serum zinc. Other factors need be evaluated to explain the residual prevalence of goitre.

Facteur de croissance IGF-1 et bilan en zinc chez des élèves du primaire présentant un goitre à Arak (République islamique d'Iran)

RÉSUMÉ Malgré le succès d'un programme national d'iodation du sel, le goitre endémique persiste toujours chez les enfants iraniens. Une étude transversale réalisée à Arak a révélé que la prévalence du goitre dans un échantillon de 6520 élèves du primaire était de 5,2\%. L'excrétion urinaire de l'iode, le profil thyroïdien, ainsi que le dosage du facteur de croissance IGF-1 et du zinc sérique ont été évalués dans des sous-échantillons de 193 enfants présentant un goitre et de 151 enfants en bonne santé. La concentration d'iode urinaire moyenne des enfants qui présentaient un goitre et des enfants sains était respectivement de 17,4 $\mu \mathrm{g} / \mathrm{dl}$ et 15,3 $\mu \mathrm{g} / \mathrm{dl}$, suggérant un apport en iode adéquat. Aucune différence significative en termes de concentration moyenne d'iode urinaire ou de taux sérique de facteur de croissance IGF-1 ou de zinc n'a été constatée entre les élèves qui présentaient un goitre et ceux qui n'en avaient pas. D'autres facteurs devront être évalués pour expliquer la persistance de la prévalence du goitre.

${ }^{7}$ Division of Endocrinology, Department of Internal Medicine; ${ }^{2}$ Division of Hormones, Department of Biochemistry; ${ }^{3}$ Division of Statistics, Department of Social Medicine, Arak University of Medical Sciences, Arak, Islamic Republic of Iran (Correspondence to M.R. Rezvanfar: rezvanfar@gmail.com).

Received: 21/02/08; accepted: 02/07/08 


\section{Introduction}

Iodine deficiency used to be common in the Islamic Republic of Iran and, after a national programme of salt iodization was set up in 1994, considerable success has been achieved in reducing endemic goitre. Nationwide monitoring in the past decade found adequate urinary iodine excretion (UIE) levels in schoolchildren, suggesting that nutritional iodine consumption was adequate $[1,2]$. Nevertheless endemic goitre still persists in Iranian schoolchildren [3].

Various explanations can be suggested for the residual prevalence of goitre, including environmental and genetic factors. There is some evidence of a positive correlation between serum insulin-like growth factor-1 (IGF-1) levels and the size of the thyroid [4] and that a decrease in serum IGF-1 levels has a favourable effect on thyroid size [5] although others have shown no correlation [6]. The interaction of thyroid hormones with zinc status has also been investigated. There are some reports that zinc deficiency may contribute to the pathogenesis of endemic goitre $[7,8]$ and affect the metabolism of thyroid hormones [9]. Another survey suggested that zinc deficiency is a goitrogenic factor that maintains and aggravates the severity of goitre endemicity in the presence of iodine deficiency [10]. Some animal studies showed that zinc deficiency can decrease serum tri-iodothyronine $\left(\mathrm{T}_{3}\right)$ and thyroxine $\left(\mathrm{T}_{4}\right)$ levels $[11]$ and that zinc supplements activate thyroid function [12].

The aim of the present study was to evaluate some of the preventable risk factors for the persistence of goitre among Iranian schoolchildren almost 10 years after mandatory iodine supplementation. We measured the prevalence of goitre and its association with UIE, thyroid hormones, IGF-1 and zinc levels in primary-school children in Arak, Islamic Republic of Iran.

\section{Methods}

The present study was a cross-sectional descriptive study, conducted during the school year 2005-06 in 16 urban government primary schools ( 8 boys' and 8 girls' schools) in Arak, the capital of Markazi province in the Islamic Republic of Iran.

\section{Sample}

The schools were chosen using a 1-stage clustered random sampling technique from 2 different educational divisions in Arak educational organization. The sites were selected to include areas with different environmental and socioeconomic characteristics.

All students in the chosen schools were included in the study and 6520 schoolchildren aged 6-11 years were screened for thyroid gland volume. Goitre was assessed clinically and assigned to 1 of 3 stages according to the World Health Organization/International Council for the Control of Iodine Deficiency Disorders/United Nations Children's Fund (WHO/ICCIDD/ UNICEF) criteria: stage 0 (no palpable or visible goitre; stage 1 (goitre detectable only by palpation and not visible when the neck is in the normal position, and including nodular glands even if not goitrous); stage 2 (goitre visible with the neck in normal position, and is consistent with an enlarged thyroid when the neck is palpated) [13].

Of 6520 children screened, 400 students aged 6-11 years (200 goitrous and 200 healthy) and their parents were selected using random number tables and invited to participate in the laboratory investigations. The exclusion criteria were the presence of any systemic chronic disease or having received prior thyroid medication. The biochemical evaluations included measurements of urinary iodine, total serum $\mathrm{T}_{4}$, total serum $\mathrm{T}_{3}$, serum thyroid-stimulating hormone (TSH), serum IGF-1 and serum zinc level.

\section{Data collection}

Casual urine samples were obtained from children in the morning hours and were frozen until analysis. Urinary iodine concentrations were measured at the University of Arak by alkaline washing, followed by iodide extraction from ash residue and spectrophotometry using the Sandell-Kolthoff reaction [14]. The normal level of urinary iodine was defined as $\geq 10.0 \mu \mathrm{g} / \mathrm{dL}$, mild iodine deficiency 5.0-9.9 $\mu \mathrm{g} / \mathrm{dL}$, moderate iodine deficiency $2.0-4.9 \mu \mathrm{g} / \mathrm{dL}$ and severe iodine deficiency $<2.0 \mu \mathrm{g} / \mathrm{dL}$.

Blood samples were obtained from the children and serum was prepared and frozen until analysis. Total $\mathrm{T}_{4}$ and total $\mathrm{T}_{3}$ were measured by radioimmunoassay (Radim EIA kit, Italy). The detection limits of the $\mathrm{T}_{4}$ and $\mathrm{T}_{3}$ assays were $4.0 \mathrm{ng} / \mathrm{mL}$ and $0.15 \mathrm{ng} / \mathrm{mL}$, and normal ranges were $45-120 \mathrm{ng} / \mathrm{mL}$ and $0.5-1.6 \mathrm{ng} / \mathrm{mL}$ respectively. Serum TSH concentration was measured by immunoenzymometric assay technique (Radim IEMA kit, Italy). The detection limit of the TSH assay was $0.1 \mathrm{mU} / \mathrm{L}$, and the normal reference range was $0.32-4.00 \mathrm{mU} / \mathrm{L}$.

Serum IGF-I was assayed by a competitive binding radioimmunoassay (Nichols Institute Diagnostics, California). The intra-assay coefficient of variation $(\mathrm{CV})$ was less than $3 \%$, and the interassay CV was less than $8.4 \%$.

The children's zinc serum status was evaluated by an improved version of the method of Lampugnani et al. [15]. The serum zinc concentration was determined by spectrophotometric methods after deproteinization of samples. The chromogen used was 4-(2-pyridylazo) resorcinol sodium salt. The interference of iron and copper ions was eliminated by masking agents. The absorbance of the obtained colour solution was recorded at $\lambda=490 \mathrm{~nm}$. The absorption was proportional to the zinc concentration. Zinc deficiency was defined as a zinc level $\leq 65 \mathrm{mg} / \mathrm{dL}[8]$. 
The ethics committee of Arak University of Medical Sciences approved the study, which was carried out in accordance with the ethical standards of the Helsinki Declaration, 1975 (revised 1983). Written permission for the study was obtained from the Education Organization of Arak city and the headteachers and chiefs of the schools involved. Parents also signed consent forms.

\section{Statistical analysis}

The differences between groups of subjects were assessed by the chi-squared and Mann-Whitney tests for comparisons between frequencies. Statistical significance was set at $P<0.05$.

\section{Results}

The clinical examinations showed that the prevalence of goitre (stage 1 and 2) among the whole schoolchild population in Arak was 5.2\%, ranging from $3.6 \%$ to $6.4 \%$ in different schools. Of the 340 children with goitre, $43.5 \%$ were classified as stage 2 according to the WHO/ICCIDD/UNICEF criteria. The prevalence of goitre increased with age, from $3.0 \%$ in children aged $6-7$ years to $6.3 \%$ in children aged 11 years $(P<0.001)$. The prevalence ofgoitre was higher in girls $(200 / 3163,6.3 \%)$ than in boys (140/3357, 4.2\%), although this was not significant statistically.
Some of the invited individuals, mainly in the healthy group, did not attend the clinic and therefore complete laboratory data were obtained for 193 children with goitre and 151 healthy children. There was no significant difference in the demographic characteristics of the goiterous and healthy groups of this subsample (Table 1).

The mean urine iodine level of goitrous children was 17.4 [standard deviation (SD 3.7)] $\mu \mathrm{g} / \mathrm{dL}$ and was not significantly different from the mean urine iodine level of healthy schoolchildren $[15.3($ SD 3.2) $\mu \mathrm{g} / \mathrm{dL}](P=0.77)$ (Table 2).

There was no significant difference in the mean serum level of IGF-1 between goitrous and healthy children [101.0 (SD 12.1) ng/mL versus 84.0 $(\mathrm{SD} 10.7) \mathrm{ng} / \mathrm{mL}](P=0.2)($ Table 2$)$.

Zinc deficiency (serum zinc level $\leq 65 \mathrm{mg} / \mathrm{dL}$ ) was found in $21(10.8 \%)$ of the goitrous children and 11 (7.2\%) of the healthy children. No children had serum zinc concentration $<55 \mathrm{mg} / \mathrm{dL}$. The mean serum zinc level of goitrous children $[84.3(\mathrm{SD} 14.1) \mathrm{mg} / \mathrm{dL}]$ was not significantly different from that of healthy children $[89.0($ SD 17.0) $\mathrm{mg} /$ $\mathrm{dL}](P=0.16)($ Table 2$)$.

The mean serum total $\mathrm{T}_{3}$ and $\mathrm{T}_{4}$ levels in zinc-deficient children were similar to those without deficiency, whereas serum TSH was significantly lower in

\begin{tabular}{|c|c|c|c|}
\hline Variable & $\begin{array}{l}\text { With goitre } \\
(n=193)\end{array}$ & $\begin{array}{l}\text { Without goitre } \\
\quad(n=151)\end{array}$ & $P$-value \\
\hline Age [mean (SD)] (years) & $9.33(1.36)$ & $8.90(1.35)$ & $0.13^{\mathrm{a}}$ \\
\hline Males [No. (\%)] & $106(55)$ & $92(61)$ & $0.26^{\mathrm{a}}$ \\
\hline Females [No. (\%)] & $87(45)$ & $59(39)$ & $0.38^{\mathrm{a}}$ \\
\hline Weight [mean (SD)] (kg) & $29(6.2)$ & $28(5.9)$ & $0.12^{\mathrm{b}}$ \\
\hline Height [mean (SD)] (cm) & $136(9.0)$ & $134(8.5)$ & $0.16^{\mathrm{b}}$ \\
\hline BMI $[$ mean $(\mathrm{SD})]\left(\mathrm{kg} / \mathrm{m}^{2}\right)$ & $15.7(1.8)$ & $15.7(1.9)$ & $0.81^{\mathrm{b}}$ \\
\hline $\begin{array}{l}\text { Educational sampling area } 1 \\
{[\mathrm{No}(\%)]}\end{array}$ & $77(40)$ & $67(45)$ & $0.53^{\mathrm{a}}$ \\
\hline $\begin{array}{l}\text { Educational sampling area } 2 \\
{[\mathrm{No}(\%)]}\end{array}$ & $116(60)$ & $84(55)$ & $0.99^{\mathrm{a}}$ \\
\hline
\end{tabular}

${ }^{a} \chi^{2}$-test; ${ }^{b}$ Mann-Whitney test.

$S D=$ standard deviation $; B M I=$ body mass index . zinc-deficient children $(P=0.04)(\mathrm{Ta}$ ble 3). Of the zinc-deficient children, $62.5 \%$ had goitre compared with only $45.1 \%$ of those without zinc deficiency, although this was not a statistically significant difference $(P>0.46)$.

\section{Discussion}

Because goitre represents maladaptation of the thyroid to iodine deficiency, a reduction of the goitre rate to $<5 \%$ in school-age children is thought to indicate the disappearance of iodine deficiency disorder as a significant public health problem [13]. In our study, the prevalence of goitre in the sample of schoolchildren in Arak was 5.2\%, which is slightly higher than this criterion but is dramatically lower than the goitre rate of $20 \%$ reported in a previous study in Arak in 1997 [16].

Our results showing that the total mean urinary iodine concentrations of the goitrous and healthy children were above the cut-off for abnormal levels indicate that theiodine supply in children's diets in Arak is adequate. It supports the suggestion that iodine deficiency was not the cause of the persistence of goitre after a decade of successful nationwide salt iodination and that other goitreogenic factors may be responsible for the continuing prevalence of goitre in this area of Islamic Republic of Iran.

Growth factors are well-documented factors regulating the proliferation of follicle cells of the thyroid in many in vitro experiments [17]. It has been demonstrated that IGF-1 stimulates cellular mitogenesis of tyreocytes, whereas TGF- $\beta 1$ inhibits the proliferation of follicle cells of the thyroid in experimental conditions [4]. In our study we did not find any significant difference in serum IGF-1 levels between goitrous and healthy children. These results were similar to Aydin et al.'s study in Turkey [6]. This might be due to the negative impact of thyroid dysfunction on IGF-1 levels. There are some other reports of a negative impact 


\begin{tabular}{|c|c|c|c|c|c|}
\hline \multirow[t]{2}{*}{ Variable } & \multicolumn{2}{|c|}{ With goitre $(n=193)$} & \multicolumn{2}{|c|}{ Without goitre $(n=151)$} & \multirow[t]{2}{*}{$P$-value } \\
\hline & Mean & $95 \% \mathrm{Cl}$ & Mean & $95 \% \mathrm{Cl}$ & \\
\hline Urine iodine $(\mu \mathrm{g} / \mathrm{mL})$ & 17.4 & $13.7-21.1$ & 15.3 & $12.1-18.5$ & $0.75^{\mathrm{a}}$ \\
\hline Serum $\mathrm{T}_{4}(\mathrm{ng} / \mathrm{mL})$ & 85.6 & $82.9-88.3$ & 85.6 & $82.6-88.6$ & $0.88^{\mathrm{a}}$ \\
\hline Serum $T_{3}(n g / m L)$ & 1.36 & $1.30-1.42$ & 1.28 & $1.22-1.33$ & $0.06^{\mathrm{a}}$ \\
\hline Serum TSH $(\mu \mathrm{g} / \mathrm{mL})$ & 2.46 & $2.04-2.88$ & 2.25 & $2.06-2.44$ & $0.25^{\mathrm{a}}$ \\
\hline Serum IGF-1 (ng/mL) & 101.0 & $76.8-125.2$ & 84.0 & $62.6-105.4$ & $0.22^{\mathrm{a}}$ \\
\hline Serum zinc ( $\mu \mathrm{g} / \mathrm{dL})$ & 84.3 & $79.9-88.7$ & 89.0 & $84.0-93.9$ & $0.11^{\mathrm{b}}$ \\
\hline
\end{tabular}

${ }^{a}$ Mann-Whitney test; ${ }^{a}$ Student $\mathrm{t}$-test.

$T_{3}=$ tri-iodothyronine; $T_{4}=$ thyroxine; $T S H$ = thyroid-stimulating hormone; IGF-1 = insulinlike growth factor

$\mathrm{Cl}=$ confidence interval.

of thyroid dysfunction or iodine deficiency on IGF-1 levels [18,19].

Mild-to-moderate zinc deficiency is common in developing countries because of a low dietary intake of zinc-rich animal-source foods, in which zinc is more bioavailable, and a high consumption of legumes and cereal grains, which contain inhibitors of zinc absorption [20-22]. No children had serum zinc concentration $<55 \mathrm{mg} / \mathrm{dL}$, below the cut-off for moderate deficiency, but serum zinc $\leq 65 \mathrm{mg} / \mathrm{dL}$, indicating mild zinc deficiency, was found in $10.8 \%$ of the goitrous children and $7.2 \%$ of the healthy children. This rate is lower than that found in other developing countries (30\%-55\%) [23,24], but still higher than in industrialized nations [25].

In our study, the plasma TSH level was significantly lower in zinc-deficient children, but serum total $\mathrm{T}_{3}$ and $\mathrm{T}_{4}$ concentrations were not affected by zinc status. $\mathrm{T}_{4}$ to $\mathrm{T}_{3}$ conversion and feedback to the hypophysis may be affected by zinc deficiency. In animal studies, severe zinc-deficient rats had flattened epithelial cells, colloid accumulation and lower $\mathrm{T}_{3}$ concentration $[26,27]$. However, the thyroid glands of zinc-deficient animals were smaller in size and pale or whitish pale in colour. Histopathologically, these glands showed atrophy and degeneration in the follicles [11]. Olivieri et al. did not find any relation between human zinc status and thyroid function [28], whereas Onishchenko et al. found that in regions exposed to some toxic metals and organic compounds zinc deficiency was a goitrogenic factor that aggravated the severity of goitre prevalence in the presence of iodine deficiency [10].

In a zinc deletion-repletion study carried out in humans, $\mathrm{TSH}$, total $\mathrm{T}_{4}$ and free $\mathrm{T}_{4}$ tended to decrease during the depletion phase and returned to control levels after zinc repletion [29]. Those results suggested that zinc may play an important role in thyroid hormone metabolism, although the exact mechanism by which zinc affects thyroid hormone function is far from clear.

Some of the selected children did not complete the survey and this was a limitation of the present study. Furthermore, as our study was limited to data from 16 urban schools in Arak it may not be possible to generalize the results to the whole schoolchild population of Islamic Republic of Iran.

To summarize, normal levels of urine iodine were found in both goitrous and healthy children. We found no significant differences in thyroid hormone, zinc, iodine or IGF-1 levels between goitrous and healthy schoolchildren. There was no significant difference in the prevalence of goitre between children with low and normal zinc levels. Further studies are needed to explain the residual prevalence of goitre the Islamic Republic of Iran.

\section{Acknowledgements}

The authors are indebted the General Office of Education and Training in Arak city and the head teachers and chiefs of the schools for their kind cooperation. We are extremely indebted to the authorities of the Research Deputy of Arak University of Medical Sciences for their financial and logistic support. We are most grateful to the laboratory centres of Vali-Asr hospital and the biochemistry department. 


\section{References}

1. Salarkia $\mathrm{N}$ et al. Evaluation of the impact of an iodine supplementation program on severely iodine-deficient schoolchildren with hypothyroidism. Public health nutrition, 2003, 6:529-33.

2. Azizi $\mathrm{F}$ et al. Goiter prevalence, urinary iodine excretion, thyroid function and anti-thyroid antibodies after 12 years of salt iodization in Shahriar, Iran. International journal for vitamin and nutrition research, 2002, 72:291-5

3. Azizi $\mathrm{F}$ et al. Sustainable control of iodine deficiency in Iran: beneficial results of the implementation of the mandatory law on salt iodization. Journal of endocrinological investigation, 2002, 25:409-13.

4. Brzozowska M et al. Stezenie IGF-1 i TGFbeta-1 w surowicy krwi a wielkosc tarczycy u dzieci z prawidlowym wydalaniem jodu w moczu [The level of IGF-1 and TGF-beta-1 in the blood serum and the thyroid size in children with normal ioduria] Endokrynologia, diabetologia i choroby przemiany materii wieku rozwojowego, 2005, 11(4):215-20.

5. Cannavò $\mathrm{S}$ et al. Goiter and impairment of thyroid function in acromegalic patients: Basal evaluation and follow-up. Hormone and metabolic research, 2000, 32(5):190-5.

6. Aydin $\mathrm{K}$ et al. Insulin-like growth factor-1 and insulin-like growth binding protein-3 levels of children living in an iodine and selenium deficient endemic goiter area. Biological trace element research, 2002, 90(1-3):25-30.

7. Farkhutdinova LM. The goiter as a biogeochemical problem. Doklady Akademii nauk, 2004, 396:705-6.

8. Ozata $\mathrm{M}$ et al. lodine and zinc, but not selenium and copper, deficiency exists in a male Turkish population with endemic goiter. Biological trace element research, 1999, 69:211-6.

9. Kralik A et al. Influence of zinc and selenium deficiency on parameters relating to thyroid hormone metabolism. Hormone and metabolic research, 1996, 28:223-6.

10. Onishchenko GG, Zaitseva NV, Zemlianova MA. [Prevention of endemic goiter in areas jointly exposed to natural and industrial chemical factors]. Gigiena i sanitaria, 2004, 1:12-7 [in Russian].

11. Gupta RP et al. Effect of experimental zinc deficiency on thyroid gland in guinea-pigs. Annals of nutrition and metabolism, 1997, 41:376-8

12. Baltaci AK et al. Opposite effects of zinc and melatonin on thyroid hormones in rats. Toxicology, 2004, 195:69-75.

13. WHO/UNICEF/ICCIDD. Assessment of iodine deficiency disorders and monitoring their elimination: a guide for programmer manager, 2nd ed. Geneva, World Health Organization, 2001.
14. Pino $\mathrm{S}$ et al. Ammonium persulfate: a safe alternative oxidizing reagent for measuring urinary iodine. Clinical chemistry, 1996, 42:239-43.

15. Lampugnani $L$ et al. A simple colorimetric method for the zinc assay in blood. Analytical letters, 1990, 23:1665-83.

16. Fani A. Thyroid diseases and goiter in Markazi province. Medical journal of Arak, 2000, 5:221-34.

17. Carneiro $\mathrm{C}$ et al. TGF-betal actions on FRTL-5 cells provide a model for the physiological regulation of thyroid growth. Oncogene, 1998, 16(11):1455-65.

18. Alikasifoglu A et al. Serum insulin-like growth factor-I (IGF-I) and IGF-binding protein-3 levels in severe iodine deficiency. Turkish journal of paediatrics, 2002, 44(3):215-8.

19. Iglesias et al. Serum insulin-like growth factor type 1, insulin-like growth factor-binding protein-1, and insulin-like growth factorbinding protein-3 concentrations in patients with thyroid dysfunction. Thyroid, 2001, 11(11):1043-8.

20. Rosado JL. Zinc and copper: proposed fortification levels and recommended zinc compounds. Nutrition, 2003, 133:2985S9S.

21. Black RE. Zinc deficiency, infectious disease and mortality in the developing world. Journal of nutrition, 2003, 133:1485S-9S.

22. Gibson RS. Zinc: the missing link in combating micronutrient malnutrition in developing countries. Proceedings of the Nutrition Society, 2006, 65:51-60.

23. Bhatnagar $\mathrm{S}$ et al. Zinc in child health and disease. Indian journal of pediatrics, 2004, 71:991-5.

24. Hettiarachchi $\mathrm{M}$ et al. Prevalence and severity of micronutrient deficiency: a cross-sectional study among adolescents in Sri Lanka. Asia Pacific journal of clinical nutrition, 2006, 15:56-63.

25. Hampel R et al. Serum zinc levels and goiter epidemiology in Germany. Zeitschrift für Ernährungswissenschaft, 1997, 36:12-5.

26. Ruz M et al. Single and multiple selenium-zinc-iodine deficiencies affect rat thyroid metabolism and ultrastructure. Journal of nutrition, 1999, 129:174-80.

27. MorleyJE et al. Zinc deficiency, chronic starvation, and hypothalamic-pituitary-thyroid function. American journal of clinical nutrition, 1980, 33:1767-70.

28. Olivieri $\mathrm{O}$ et al. Selenium, zinc, and thyroid hormones in healthy subjects: low $\mathrm{t} 3 / \mathrm{t} 4$ ratio in the elderly is related to impaired selenium status. Biological trace element research, 1996, 51(1):31-41.

29. Wada L et al. Effect of low zinc intakes on basal metabolic rate, thyroid hormones and protein utilization in adult men. Journal of nutrition, 1986, 116:1045-53 